\title{
Women in education: A review of Indonesian feminism
}

\author{
Yuliati*, M.N.L. Khakim \& Idris \\ Universitas Negeri Malang, Malang City, Indonesia
}

\begin{abstract}
Suwardi Suryaningrat or better known as Ki Hajar Dewantara, is one of the legendary teachers of Indonesia. Politicians, educators, humanists, statesmen and other titles have been held by him. Few people know that his character also includes being a feminist. Ki Hajar Dewantara's thoughts about Indonesian women, especially Javanese published in Wasita Rini, should be known and used as a timeless reference. Wasita Rini emphasizes important teachings for women regarding the concept of freedom, discipline, morality and the role which contains women's rights and obligations. This teaching is useful for Indonesian girls or women to remain virtuous in utilizing their independence.
\end{abstract}

Keywords: Women, education, Indonesian feminism.

\section{INTRODUCTION}

The majority of Indonesian historical writings are written by men so that historical works give the existence of this country like men (androcentric). This is proven by (Purwanto \& Nursam 2006) through the example of Abdurrachman Suryomihardjo's dissertation which describes social development in Yogyakarta that seems to be only carried out by men. The female historian, Darsiti Soeratman, apparently still used the male narrative when writing the World Life of Kraton Surakarta in 1930, while Djuliati Suroyo did not discuss gender inequality in revealing labor during the Cultivation Period in Kedu. Then Asvi Warman Adam, a historian at LIPI, in his essay, made clear Bambang Purwanto's statement that the three historians' dissertations were guided by a senior historian who was loyal to the field of history, namely Sartono Kartodirdjo (Adam 2007). From there, Purwanto and Nursam (2006) concluded that consciously or not, the historiographic reality of women has been neglected as part of the historical process of Indonesia. The androcentric history of Indonesia was also stated by Asvi Warman Adam, which was filled with political and military topics, which had the dimensions of male strength in wars and power struggles. Asvi Warman Adam then opened our memories of the opinion that was once expressed by Kuntowijoyo to start a business with the theme of women in historical research, (Soeri Soeroto \& Frederick 1928) which had also been suggested.

Therefore, it is important to write women's histories in line with the times. This study aims to complement our previous research on the history of women in Indonesia (Yuliati et al. 2019; Khakim et al. 2020). One of the important figures who initiated education for women in the early days of Indonesian independence was Ki Hadjar Dewantara. Suwardi Suryaningrat or better known as Ki Hajdar Dewantara is known as a pioneer figure in education in Indonesia. The role of Ki Hajar Dewantara in developing Indonesian education is based on local wisdom values. During the Dutch colonial period until independence in Indonesia, education was primarily for men. However, not many people know that Ki Hajdar Dewantara has paid attention to education for Indonesian women. This article aims to discuss how education and gender equality according to Ki Hajar Dewantara became a foundation in developing Indonesian women in the future.

\footnotetext{
*Corresponding author: yuliati.fis@um.ac.id
} 


\section{METHOD}

The method of this research is literature study. Literature research method or literature study is a way of activities related to data collection methods, reading, reviewing and recording and analyzing research materials (Zed 2004). This research method was in accordance with the preparation of this article because it used books, journals, and articles related to Ki Hadjar Dewantara's Review about women's education in Indonesia. The researcher read all the literature on the history of Ki Hadjar Dewantara's review about women's education in Indonesia and then noted and summarized the essential parts. The results of the summary were analyzed by historical methods.

This literature study method was complemented by the historical method because the focus of this study was on Ki Hadjar Dewantara's Review about women's education in Indonesia. This historical method was properly selected because it upholds interpretation and analysis in historiography. The historical method is a way or steps in rebuilding past events, through four stages of research, namely heuristics, source criticism, interpretation, and historiography (Hamid \& Madjid 2011). Heuristics or collecting reference sources on Ki Hadjar Dewantara's review about Women Education in Indonesia. It was complemented by a critique of the accuracy of relevant reference sources. Interpretation from each source was used to reconstruct Ki Hajar Dewantara's review about women's education in Indonesia. Historiography was used to write the results of reconstruction chronologically and scientifically.

\section{RESULT AND DISCUSSION}

The most essential women's problems that cannot be denied is their nature. Women's nature is a reality that is not undeniable, that becomes the right and a pointer if people think about women (Dewantara 1928). Women's nature in Indonesia is different from woman's nature in Europe. In Europe, women have struggled hard to get various kinds of equality with men. The aspirations that women want to achieve in Europe are indeed right, but the movement to get equality with men eventually leads to conditions that fail to match the nature of women.

The emancipation of European women fights for the equality of rights and equality in every aspect. Equality of rights is no longer becomes their single demand, but equality in various aspects, such as in dressing, getting pleasure, life, work and so forth. The description of the European women's struggle who demand equality in all fields of life at that time was considered harming their natures by Ki Hadjar Dewantara. They forget that a woman's body is different from a male body. The difference is related to the nature of women who should be mothers, get pregnant, and give birth.

Women's issues become important issues. A woman is the symbol of the perfection of human life. During the life of a woman, the divine command of God instructed to guard them, because if there is purity there is a contradiction, which can plunge women into disgrace and misery.

Problems about women for Tamansiswa are not only confusing to the realm of education but also developing into other domains, for example, politics and economics. Consequently, its effects cannot be predicted in advance. In an article addressed to the police, Ki Hajar Dewantara reminded of the duty of a police officer to maintain order and peace in the community, so that the customs of the people in charge must be known. For example, a Javanese proverb that reads "earth's smile, a bath of water, acts of death." This proverb shows us that all disputes between our communities regarding the struggle over land even though only a few inches of land and power struggles over women, even if only in the form of a forehead is usually brave. According to the opinion of Europeans who have different customs with Indonesian people, the above issue of femininity is considered as an insignificant problem, even kissing a person's wife, that are considered strange by our customs, may be judged only by a fine of 2.5 rupiahs, which is considered an unfair trial by us (Ki Hajar et al. 2002).

In the proverb above, women as the descendants that must be pure in their lives both physically and mentally. Every now and then there should not be any doubt about whom men are entitled 
to participate in the derivative that was born by the woman. In the multiplication, according to natural law women are the descendants of descendants, while men are the masters of descent. In this respect, the law of each country determines the rights and obligations of husband and wife, as well as father and mother. For this reason, marriage intends to eliminate the doubt as much as possible. Likewise, religious rules and traditions in the community aims to purify marriage between two humans, men and women that have been legalized by state law.

The proverb "senyari bumi sedumuk bathuk" contains the symbol of the immortality of human life in the world. The dead man expects his offspring to remain in the world. Consequently, it causes the derivative in human life is considered an important matter, as it seems to be "eternity" or "immortality." Since women give birth to a child, then they are considered as a symbol of immortality in the world and therefore human beings can save their lives to protect the purity of the life of women who are their dependents (Dewantara 2002).

Ki Hajar Dewantara's legacy aimed at women was Wasita Rini, a song in Javanese (tembang) with the song Asmarandana. Wasita Rini means advice for women. Its contents are about the teachings of decency as a provision to get personal safety. Ki Hajar Dewantara does not elaborate on this teaching in detail, with the intention that women are more flexible in giving interpretations, adapted to space and time or nature and time, so that they can think and act creatively, without leaving the subject matter.

The granting of poetry forms to Wasita Rini is intended to allow users of this teaching to easily remember its contents. Besides, the contents of the text are expected to not be easily displaced. Wasita Rini was composed around the 1940s, during which Javanese society had had several old (fiber) books containing advice for women, for example, Wulang Puteri, Wulang Estri and Wasitaning Istri (Soeratman 1996). Its complete verse is interpreted below.

1. The teachings of femininity, in ancient times and now, are both indispensable. Both of them intend to keep the women pure, safe and avoiding dangers.

2. The difference in this age is called the era of independence, where the whole community against the power and authority of others. That's how women do not like to be treated by others.

3. Remember women, independence does not just mean free from the command of others, but also must be strong and capable of self-control. Therefore, do not forget that rights and obligations are inseparable.

4. The so-called obligation is all the readiness and willingness of birth and mind. It follows the right to self-will. Remember that you have scales to weigh what is good and what is not.

5. Women who maintain the spirit of independence must know the importance of the intelligence of hope and the creation of life independence, while morality is a safety fence for the women.

In relation to the widespread expansion of free life, Ki Hajar Dewantara emphasizes this teaching on the implementation of the concept of "independence" and "morality." According to Ki Hadjar, independence is one of human nature, which is sublime and beautiful. Meanwhile, morality is the nobleness and beauty of human life. Independence which is culturally human nature has two properties of external nature that is free or loose from the coercion or other commands of the other, and the inner nature, which is independent or stand-alone (Dewantara 1964a).

Human virtue shows the nature of his inner life, for example, conviction about purity, freedom, justice, divinity, love, loyalty, order, peace, sociality and so forth. Decency or subtlety shows the subtle and beautiful outward nature of man. Teaching about nobility or attitude and morality also teaches all human rights and obligations, both as a person and as a member of society (Dewantara 1964b).

Ki Hajar Dewantara's teachings for women in the form of discourses entitled Sengkala Candra and song lyrics are part of the entire education system that applies anywhere not only in the Taman Siswa neighborhood. It uses to challenge an increasing number of elements of foreign culture borrowed, especially those from the West, including social courtesy among teenage boys and girls. The teachings used in Tamansiswa, for example, Wasita Rini can still be used as a guide. Wasita Rini, who gave the basic concepts of independence and decency, is quite flexible in its implementation 
following the development of society, especially the relationship between women and men who increasingly wanted freedom in the association. In this case, it is necessary to inculcate the use of rights and obligations that must be balanced under the status that is carried.

\section{CONCLUSIONS}

Education by Suwardi Suryaningrat was given the connotation of planting the seeds of independence, namely only independent warriors who were able to win independence. It begins by joining the Tuesday Kliwon Circle of Friends which aims to bring about the happiness of self, nation and humanity. The Circle of Friends was dissolved after its goal was realized with the establishment of Tamansiswa. For advice directed at women, Ki Hajar Dewantara has created a song entitled Wasita Rini. In Wasita Rini's lyrics, it is explicitly mentioned that the rights and obligations of someone are essentially inseparable, appearing together equally. This is the foundation of the real understanding of democracy.

In addition, Tamansiswa also established a women's dormitory, called Wisma Rini, whose management was handed over to Tamansiswa Women. Wisma Rini was a dormitory that was used as a residence for female students whose homes were far away because Tamansiswa was a school in the form of a schoolhouse. It is a school that is also used as a house for the tutors so that students could feel at home.

\section{REFERENCES}

Adam, A. W. (2007) 'Perempuan Dalam Sejarah Lelaki', Jurnal Perempuan, 52, pp. 7-18.

Dewantara, K. H. (1928) 'Nature of women', Wasita, I, p. 80.

Dewantara, K. H. (1964a) 'Azas-azas dan Dasar-dasar Tamansiswa', Majelis Luhur Tamansiswa, a.

Dewantara, K. H. (1964b) 'Pendidikan', Majelis Luhur Tamansiswa, b.

Dewantara, K. H. (2002) 'Women's Community Development Center "Nyi Hadjar Dewantara", Problem Women in Yogyakarta.

Hamid, A. R., \& Madjid, M. S. (2011) Pengantar Ilmu Sejarah. Ombak.

Khakim, M. N. L. et al. (2020) 'Identification of tourism potentials in Ancient Bathing Sites of Pasuruan, Indonesia', in IOP Conference Series: Earth and Environmental Science. doi: 10.1088/1755-1315/ 485/1/012099.

Ki Hajar, Dewantara \& Dewantara, N. H. (2002) Wanita. Pusat Pengembangan Komunitas Perempuan Nyi Hajar Dewantara.

Purwanto, B. and Nursam, M. (2006) Gagalnya Historiografi Indonesiasentris?! Ombak.

Soeratman, D. (1996) Dari Ki dan Nyi Hajar Dewantara sampai Pergerakan Wanita Indonesia. BP Wanita.

Soeri Soeroto and Frederick, W. H. (1928) Pemahaman sejarah Indonesia?: sebelum dan sesudah revolusi. Jakarta: LP3S.

Yuliati, Y., Hakim, N. L. and Towaf, S. M. (2019) 'Kartini's Contribution in Developing the Art of Carving Macan Kurung Jepara (1903)', in. doi: 10.2991/icskse-18.2019.27.

Zed, M. (2004) Metode peneletian kepustakaan. Yayasan Obor Indonesia. 